\title{
2007 Annual report and plans for 2008
}

\section{Journal website, www.thepcrj.org}

Since moving to our new publishers in January 2007, there have been a number of new developments for the PCRJ. One of the key changes has been the setting up of the journal website at www.thepcrj.org. The website provides worldwide access, free of charge, to all PCRJ papers - not just past papers but immediate access to current papers too. From an ethical perspective we are delighted that we have been able to make the journal available free of charge to clinicians and researchers worldwide; in doing so we have also fulfilled one of the challenges laid down to us by the International Primary Care Respiratory Group (IPCRG) two years ago.'

Figure 1 shows the webste visit statistics from 1st January through to October 2007.

On average, 200 people access the site every day, looking at $21 / 2$ pages on average and spending an average $21 / 4$ minutes on the site.

Figure 2 shows the sources of referrals/access to the site. It can be seen that over $50 \%$ of visitors to the site come from Medline/PubMed, and $8 \%$ come from the GPIAG website.

With this sort of website availability, several papers have had high numbers of downloads - as shown in Table 1. For example, the paper by Andy Bush on the diagnosis of asthma in children under five ${ }^{2}$ has been downloaded almost 9000 times between February and September, and the IPCRG guideline papers have been downloaded nearly 7000 times. We hope that these high numbers of downloaded papers will start being reflected in increased PCRJ paper citations in 2008.

Future development of the journal website is entirely dependent on funding availability, and is uncertain in the near future. However we are just about to go live with our new online submission system via Manuscript Central. As soon as we are able (i.e. when we have the budget) we hope to include listings of the most frequently downloaded and most frequently cited papers, together with the facility for readers to download citations into reference management software as well as a facility to download slides of graphs and tables for personal use. We also hope to develop targeted e-alerts to encourage reader citations, and finally, we hope to implement a new project with SCOPUS to add author publication activity and personal $\mathrm{H}$-Index scores (a measure of personal citations) on the website - all of which should increase website traffic and publication submissions.

\section{Paper submissions in 2007}

As at the end of September, we had received 67 original paper submissions, compared with 91 for the whole year in 2006. While we continue to attract $40 \%$ of our papers from outside the UK, this proportion is slightly reduced compared with 2006. Our acceptance rate for papers is approximately $84 \%$ - higher than last year - but we feel that this comfortably reflects the increased quality of submissions in general (Table 2).

\section{Marketing}

Our new publisher has been actively marketing the journal, particularly by sending copies of the journal and calls for papers to the ATS, which were distributed by the GPIAG committee. There was a PCRJ stand at the ERS in Stockholm which was very well attended, and at which many copies of the journal and calls for papers were distributed.

\section{Citations}

One of our major aims is to increase the number of PCRJ papers being cited in peer-reviewed journals. We have no doubt that, with the free worldwide access to PCRJ papers now available because of the journal website, and with the encouraging website statistics available so far this year, increased citations for journal papers will follow. However, we are constantly looking at ways in which we can help develop citations further, and possible solutions include speeding up the handling of accepted papers so that they appear online as soon as possible, further development of the website, marketing of papers through an e-alert system, and working with colleagues to ensure that they're aware of PCRJ papers in their specific field. 


\section{Visitors Overview}

1 Mar 2007 - 28 Oct 2007

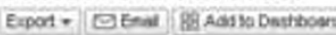

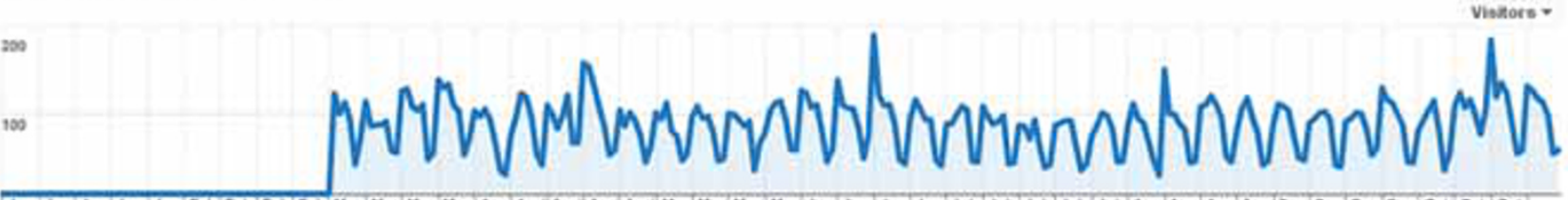
16,543 people visited this site
_munturat 22,674 Visits
16,543 Absolute Unique Visitors
Jintaine 65,516 pageviews
Hathe 2.89 Average Pageviews
00:02:16 Time on Site
$57.13 \%$ Bounce Rate
$72.98 \%$ Now Vicits

\section{Visitor Segmentation}

8 Visitors Profile: lanquages, network locations, user defined

Browser Profile: browsers, operating syctems, browser and operating sytems, screen colors, screen resolutions, lava support, Flash

(6) Map Overlay

Ceciocstion visunitistion

Figure 2. Sources of referrals to $w w w$,thepcrj.org

\section{All Trenter}

All Traffic Sources

1 Mar 2007 - 28 Oct 2007

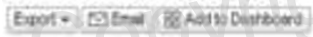

200

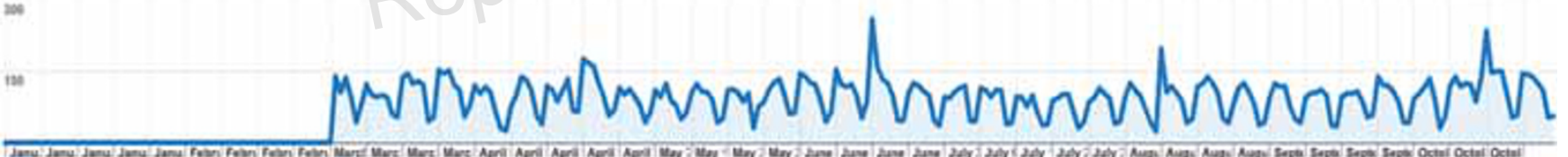

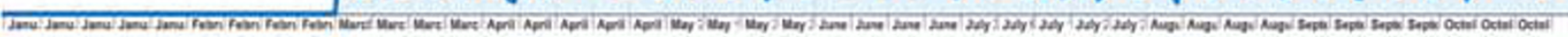

All traffic sources sent 22,674 visits via 714 sources and mediums

ser sauka Mudiam z

Sinteusave Goal Comerision

\begin{tabular}{|c|c|c|c|c|c|c|c|c|c|c|}
\hline & 674 & (1) & $\begin{array}{l}\text { Pagusdist } \\
\mathbf{2 . 8 9} \\
\text { Site Aug. } 289 \text { (a.oosis }\end{array}$ & (1) & $\begin{array}{l}\text { Avg Time on Site } \\
\text { 00:02:16 }\end{array}$ & (c) & $\begin{array}{l}\text { S New Vats } \\
72.97 \% \\
\text { Btar Ang } 72.94 \text { poons }\end{array}$ & () & $\begin{array}{l}\text { Bounce Rate } \\
57.13 \% \\
\text { Ste Neg } 57.13 \text { s }\end{array}$ & (1) \\
\hline & reavidin & & & & Yinata $\downarrow$ & enenvat & Ang tireenste & & Newnats & Buncesats \\
\hline 1. & estiringharitutns & & & & nte & +134 & cot: 25 & & ness & 6osts \\
\hline 2. & testentioores & & & & มี & 258 & $\infty \cos _{21}$ & & sarss & $\cos x$ \\
\hline 3. & resciterars & & & & 2,30 & 320 & $\infty 001.52$ & & $73.46 \%$ & 8865 \\
\hline 4 & absealatens & & & & 1,912 & 632 & coross & & $5136 x$ & $2202 x$ \\
\hline 5. & mesceneratintens & & & & es & 460 & $\infty 0<0$ & & $\operatorname{sen} 20 x$ & 20564 \\
\hline a. & enionars & & & & $m$ & 200 & coses & & si. $18 \pi$ & nster. \\
\hline 7. & nocterims & & & & $2 n$ & $4 \pi$ & $\infty 020205$ & & 0.350 & zaots \\
\hline 4. & entenas & & & & 188 & 324 & $\infty 024$ & & $\operatorname{mas}$ & $6.13 \times$ \\
\hline 3. & etrecinlinters: & & & & $\mathbf{n}$ & 8.12 & $\cos 20$ & & ess & $2 \pi \pi \times$ \\
\hline 10. & waschivars & & & & $\pi$ & 289 & pot:28 & & $2684 \pi$ & $63.16 x$ \\
\hline
\end{tabular}


Table 1. Top 10 downloaded papers on the PCRI w ebsite, 2007 (all available at ww w.thepcrj.org - Vol 16 2007).

\begin{tabular}{|c|c|c|c|c|c|c|c|c|c|c|}
\hline \multirow[b]{2}{*}{ Paper } & \multicolumn{10}{|c|}{ Times downloaded } \\
\hline & Jan & Feb & Mar & Apr & May & Jun & Jul & Aug & Sep & | Total \\
\hline $\begin{array}{l}1 \text { Diagnosis of asthma in children under five } \\
\text { Andrew Bush. Online } 7 \text { February } 2007\end{array}$ & & 719 & 1195 & 1620 & 1603 & 851 & 964 & 1178 & 834 & 8964 \\
\hline $\begin{array}{l}2 \text { International Primary Care Respiratory Group (IPCRG) Guidelines: } \\
\text { Management of Chronic Obstructive Pulmonary Disease (COPD) } \\
\text { David Bellamy, Jacques Bouchard, Svein Henrichsen, Gunnar Johansson, } \\
\text { Arnulf Langhammer, Jim Reid, Chris van Weel and Sonia Buist. } \\
\text { Online February } 2006\end{array}$ & 424 & 702 & 540 & 508 & 508 & & & & 458 & 3140 \\
\hline $\begin{array}{l}3 \text { COPD screening efforts in primary care: what is the yield? } \\
\text { David G Tinkelman, David Price, Robert J Nordyke and } \\
\text { Ronald J Halbert. Online } 10 \text { February } 2007\end{array}$ & & 1128 & 705 & 516 & & 502 & & & & 2851 \\
\hline $\begin{array}{l}5 \text { The properties of inhaled corticosteroids: similarities and differences } \\
\text { Neil C Barnes. Online } 27 \text { May } 2007\end{array}$ & & & & & & 855 & 790 & 496 & & 2141 \\
\hline $\begin{array}{l}6 \text { Inhalation therapy: an historical review } \\
\text { Mark Sanders. Online } 13 \text { March } 2007\end{array}$ & & $\theta$ & & & & 636 & 597 & 460 & & 1693 \\
\hline $\begin{array}{l}7 \text { Asthma: 1987-2007. What have we achieved and what are the } \\
\text { persisting challenges? } \\
\text { Martyn R Partridge. Online } 27 \text { May } 2007\end{array}$ & & & & & & 900 & 527 & & & 1427 \\
\hline $\begin{array}{l}10 \text { International Primary Care Respiratory Group (IPCRG) Guidelines: } \\
\text { Diagnosis of respiratory diseases in primary care } \\
\text { Mark L Levy, M onica Fletcher, David B Price, Thomas Hausen, } \\
\text { Ron J Halbert and Barbara P Yawn. Online February } 2006\end{array}$ & 320 & & 652 & & & & & & & 972 \\
\hline
\end{tabular}

\section{Funding/frequency of issues}

In the present financial climate it is becoming increasingly challenging to produce a high quality peer-reviewed academic journal in paper format which also provides free worldwide online access to current journal papers. We are currently in discussion with our publisher and the Trustees of the GPIAG (the owners of the PCRJ) regarding the format of the PCRJ next year. In general, we see the journal website as the way forward, but we are all agreed - editors, publisher, GPIAG Trustees and International Editorial Board members that a hard copy publication, in addition to the online publication of papers, is highly preferable. One possible solution is that the hard copy journal will revert to being a quarterly publication; this will clearly delay print publication but we will 
Table 2. Papers received by the PCR in 2007 compared with 2006.

\begin{tabular}{|c|c|c|}
\hline PCRJ Stats 2007 & 2006 & To Sep 2007 \\
\hline New manuscripts received & 91 & 67 \\
\hline Number of commissioned papers & 7 & 12 \\
\hline Total papers submitted & 99 & 79 \\
\hline Rejection rate & (32) $36 \%$ & (12) $18 \%$ \\
\hline Total papers published\# & 57 & 56 \\
\hline $\begin{array}{l}\text { Number of papers in process/ } \\
\text { carried forward }\end{array}$ & 10 & 21 \\
\hline $\begin{array}{l}\text { Published articles by first } \\
\text { author country }\end{array}$ & Volume 15 & $\begin{array}{l}\text { Volume } 16 \\
\text { to Oct edition }\end{array}$ \\
\hline UK & 27 & 34 \\
\hline Netherlands & 9 & 1 \\
\hline USA & 7 & 4 \\
\hline Canada & 3 & 3 \\
\hline Australia & 2 & 2 \\
\hline Brazil & 0 & 1 \\
\hline Denmark & 0 & 4 \\
\hline Finland & 1 & 0 \\
\hline France & 1 & 0 \\
\hline Greece & 1 & 2 \\
\hline Kuwait & 1 & 0 \\
\hline Mexico & 0 & 1 \\
\hline Norway & 1 & 1 \\
\hline Singapore & 1 & 1 \\
\hline South Africa & 1 & 1 \\
\hline Sweden & 1 & 1 \\
\hline Syria & 1 & 0 \\
\hline $\begin{array}{l}\text { Total published items } \\
\text { (excludes abstracts and editor's } \\
\text { What's in This Issue) }\end{array}$ & 57 & 56 \\
\hline UK:Non-UK ratio & $27: 30$ & $34: 22$ \\
\hline
\end{tabular}

\# 10 papers carried forward from 2006 to 2007

Note: These figures are as accurate as possible given the difficulties faced in calculating data from three separate processing systems during the transition to new publishers in 2006/07.

A new electronic submission system will be available for 2008 calculations continue to provide a rapid 'ahead of print' publication service online. We anticipate that, in the future - as is the case for many journals - the website will be the main vehicle for publication of the PCRJ. We will notify readers of the results of our discussions, and any changes in the process of publication of the journal, on the website and in the first issue of 2008.

\section{Supplements}

We are able to announce that Dr Paul Stephenson (Deputy Editor) has been appointed Supplements Editor, with direct responsibility to the Editor-in-Chief, following a period of discussion and provisional agreement on a new supplements policy document, underpinned by a new framework for the relationship between the journal owners, the publishers and the editors of the PCRJ. These documents will be submitted to the Committee on Publication Ethics (COPE) for their advice, once finally agreed by the GPIAG Trustees.

\section{References}

1. Tomlins R, Williams S. The impact of the UK General Practice Airways Group (GPIAG) - an international perspective. Prim Care Resp J 2007;16(3):140-4. doi. 10.3132/pcrj.2007.00037

2. Bush A. Diagnosis of asthma in children under five. Prim Care Resp J 2007; 16(1):7-15. doi.10.3132/pcrj.2007.00001

\section{*Mark L Levy}

Editor-in-Chief, PCRJ; Senior Clinical Research Fellow, Allergy and Respiratory Research Group, Division of Community Health Sciences: GP section, University of Edinburgh, Scotland, UK.

\section{Paul Stephenson}

Deputy Editor, PCRJ; The Christmas Maltings and Clements Practice, Haverhill, Suffolk, UK.

\section{*Correspondence:}

c/o GPIAG, Smithy House, Waterbeck, Lockerbie, DG11 3EY, UK.

Tel: +44 (0)1461 600639 Fax: +44 (0)1461 207819

E-mail: marklevy@animalswild.com

\section{Available online at http:// w w w.thepcrj.org}

